\title{
Reproductive Rebellions in Britain and the Republic of Ireland: Contemporary and Past Abortion Activism and Alternative Sites of Care
}

\author{
Ben Kasstan ${ }^{1 *}$, Sarah Crook ${ }^{2}$
}

Published: September 27, 2018

\begin{abstract}
This paper explores how feminist movements in contemporary Ireland and the Women's Liberation Movement in Britain in the 1970s and 1980s have subverted state domination and have struggled for selfgovernance of the female bodies in ways that represent a continuum of responses to restrictive legislation. We address how discourses of liberatory knowledges and autonomy can give rise to 'illegitimate' forms of self-care as well as extra-state care (or 'exile') across historically-situated points in time. Moreover, we illustrate how social resistance can influence political action surrounding abortion law reform, which can be understood as an attempt to bring the 'illegitimate' into the realm of state control and guardianship. Our comparative approach illustrates how campaigns around reproductive rights in contemporary Ireland and in 1970s and 1980s Britain continue to share three crucial strategies: to raise consciousness and awareness; to encourage mobilisation and self-organising of care at the individual and collective levels; and to seek legislative change. Mapping the continuities in how feminist campaigns configure reproductive health and the body as a site of activism in the body politic heralds renewed feminist encounters with the medical humanities, by (re)situating women's bodies in a historically contiguous struggle for reproductive justice.
\end{abstract}

Keywords: abortion, feminist epistemology, Britain, Ireland, women’s liberation movement

\section{INTRODUCTION}

Legislation surrounding abortion care in Britain and the Republic of Ireland are connected through colonial history, yet ongoing social movements to reform abortion law on both sides of the Irish Sea signal how the two contexts remain analytically interlinked. We examine how, across historically-situated points in time, feminist movements have subverted state domination and have struggled for self-governance of the body in ways that represent a continuum of responses to restrictive legislation. Through an examination of the contemporary struggle in Ireland and an exploration of the activism of the Women's Liberation Movement in Britain in the 1970s and 1980s, we address how discourses of liberatory knowledges and autonomy can give rise to 'illegitimate' forms of self-care as well as extra-state care (or 'exile'). Moreover, we illustrate how social resistance can influence political action surrounding abortion law reform, which can be understood as an attempt to bring the 'illegitimate' into the realm of state control and guardianship. We take the increasing yet 'illegitimate' procurement of medical abortion (the exclusive use of Misoprostol or in combination with Mifepristone) ${ }^{1}$ among women in both Britain and Ireland (cf. Sheldon, 2016; Aiken et al., 2018) as a signal of how reproductive rebellions are exposing the current limits of abortion legislation. Our comparative approach illustrates how campaigns around reproductive rights in contemporary Ireland and in 1970s and 1980s Britain continue to share three crucial strategies: to raise consciousness and awareness; to encourage mobilisation and self-organising of care at the individual and collective levels; and to seek legislative change. Mapping the continuities in how feminist campaigns configure reproductive health and the body as a site of activism in the body politic heralds renewed feminist encounters with the medical humanities, by (re)situating women's bodies in a historically contiguous struggle for reproductive justice.

${ }^{1}$ Medical abortion (informally described as the "abortion pill") is used to terminate pregnancies of up to ten weeks' gestation, and consists of administering Mifepristone usually followed by Misoprostol, or Misoprostol alone (which can be less effective).

${ }^{1}$ Research Fellow in the Department of Anthropology, University of Sussex, UNITED KINGDOM

2 Sarah Crook is the Sir Christopher Cox Junior Fellow at New College, University of Oxford, UNITED KINGDOM

*Corresponding Author: b.kasstan@sussex.ac.uk 


\section{HISTORICAL AND ANTROPOLOGICAL APPROACHES TO ACTIVISM}

Creating a dialogue between reproductive rights movements in contemporary Ireland and 1970s-1980s Britain illustrates the continuities and discontinuities through which feminist discourses of bodily knowledge and autonomy have spearheaded responses to restrictive legislation over time. The anthropological contributions to this paper involved content analysis of activist discourse circulated via social media portal Twitter, Irish media, and the websites of key Irish organisations promoting reproductive rights and bodily autonomy in the run up Ireland's Referendum to repeal the Eighth Amendment on 25 May 2018. We focused particularly on the Abortion Rights Campaign and The London-Irish Abortion Rights Campaign as leading and influential protagonists of activism in Ireland and the Irish diaspora. BK travelled to Dublin on 24 September 2016 to provide an ethnographic critique of abortion protest activities. Using an interpretive grounded theory approach for the anthropological research enabled us to analyse the historically contiguous patterns that emerged directly from the discourse under study.

The historical components focused on the significance of self-care and the dissemination of knowledge about the body in Britain in the 1970s and 1980s draws upon archival materials relating to the Women's Liberation Movement, as well as texts that drew upon the movement's values. The Women's Liberation Movement was conscious of the importance of curating its archive and historians of the movement work with a rich and extensive body of sources; more recently, efforts have been underway to digitise some of these sources. ${ }^{2}$ The Women's Liberation Movement had its first national conference at Ruskin College, Oxford, in 1970 and held its last national conference in Birmingham in 1978. The final conference, however, did not mark the end of feminist activism that emerged from the movement, and this article, in line with other recent scholarship, takes a longer view of the chronology of feminist activism in this period (see Thomlinson, 2016).

This interdisciplinary critique of the sites and modes of producing 'liberatory knowledges' in Ireland's contemporary movement and in 1970s Britain demonstrates how women seek change by establishing alternative or 'illegitimate' sites and models of care when state provision of reproductive healthcare is inaccessible or considered deficient, unsuitable and inadequate. Charting the ways in which restrictive legislation has provoked a continuous mandate for individual and collective self-care in feminist movements, as well as more extreme forms of extra-state care or exile, has the potential to inform debates about the medical humanities and its role in advocating for (reproductive) health justice. We envisage this paper as a provocation for the medical humanities to intervene in global public health debates around sexual and reproductive rights, and to critique the rebellions that are provoked by a pervasive movement to impose restrictive legislations around women's health and undermine their bodily autonomy. ${ }^{3}$

\section{‘LEGITIMATE’ AND ‘ILLEGITIMATE’ ABORTION CARE IN BRITIAN AND IRELAND ${ }^{4}$}

Sections 58 and 59 of the 1861 Offences Against the Person Act (OAPA), which criminalised procuring or assisting to induce a miscarriage, was enacted in Ireland under British colonial rule and became assimilated into Irish law following independence in 1922 (see Oaks, 1999; Irish Statute Book, 1861). Article 40.3.3, inserted into the Irish Constitution by its Eighth Amendment by way of public referendum in 1983, formalised opposition to abortion and is influenced by the Roman Catholic cosmology — positioning women's bodies (and the governance of bodily and reproductive conducts) in the gaze of a political union between "church and state." 5 This 1983 referendum was itself a product of historical circumstance; Fiona de Londras and Máiréad Enright (2018: 3) have explained it as 'at once a pre-emptive strike against any further liberation for woman, and a backlash against the limited liberation that had already occurred.' It made Ireland the world's first country to 'constitutionalize fetal rights' (de Londras, 2015) by stating that the 'unborn' embryo or foetus has an equal right to life to the pregnant woman:

The State acknowledges the right to life of the unborn and, with due regard to the equal right to life of the mother, guarantees in its laws to respect, and, as far as practicable, by its laws to defend and vindicate that right. (Eighth Amendment of the Constitution Act, 1983, Irish Statute Book)

Under Irish law, 'legitimate' terminations of pregnancy are, in theory, only permitted when a woman's life is perceived by clinicians to be 'at real and substantial risk' (Protection of Life During Pregnancy Act, 2013, Irish

\footnotetext{
${ }^{2}$ See, for example, the British Library's project to digitise Spare Rib https:/ / mmm.bl.uk/ spare-rib

${ }^{3}$ See Guttmacher Institute resources on 'reproductive health in crisis'; Gold and Starrs (2017).

${ }^{4}$ We offer a brief sketch of British and Irish abortion legislation to contextualise historical and on-going activism on both sides of the Irish Sea.

5 A range of Amendments followed the 1983 Referendum as well as the Protection of Life During Pregnancy Act 2013 (which repealed Sections 58 and 59 of the 1861 Offences Against the Person Act).
} 
Statute Book). What determines this prerequisite threat to a woman's health is far from clear-cut, with medical professionals instead being entrusted with the responsibility to grant access to abortions based on their interpretations of what have been termed 'Catholic health policies' (Berer, 2013). There have been numerous examples in recent years where existential threats to a woman's health that should warrant a 'legitimate' abortion in Ireland (including mental health and attempted or risk of suicide) - have been overlooked, if not dismissed altogether (cf. Side, 2016: 1794). ${ }^{6}$ Thus healthcare professionals are arguably unable to offer woman-centred and medically appropriate care and instead provide services that are constitutionally permissible (de Londras, 2015), a reality that is said to have a 'significant chilling factor' for both women and physicians involved in consultations around abortion care (European Court of Human Rights, 2010). Just twenty-five abortions were performed under state care in 2016 (Department of Health, 2017), forcing the majority of women to either procure terminations as part of self-care strategies or access extra-state abortion care, which we go on to frame as a form of 'reproductive exile.' At the time of writing (July 2018), abortion legislation in the Republic of Ireland is among the most restrictive in the world (Enright et al., 2015). Any person who procures an abortion (such as by self-medication) or assists somebody to procure an abortion outside the confines of Irish law can face imprisonment for up to fourteen years. A protracted, subversive, and highly visible public campaign led by reproductive rights activists culminated in the announcement of a decisive Referendum result to repeal the Eighth Amendment on 26 May 2018, giving clear a mandate to reform and resolve Ireland's constitutional impasse. Policy-makers have since been tasked with designing replacement abortion legislation, but the framework within which abortion care will be provided as of yet remains unclear.

It is important to note that there are key differences between the current British and (shifting, post-Repeal) Irish landscapes. Abortion care in England, Scotland and Wales is available until twenty-four weeks of gestation, ${ }^{7}$ and is funded by the National Health Service (NHS) in the vast majority of cases with care outsourced to the independent sector (Abortion Statistics, England and Wales, 2017). ${ }^{8}$ The 1967 Abortion Act makes 'legitimate' abortion care in England, Scotland and Wales available under certain conditions, and provides exceptions to sections 58 and 59 of the 1861 OAPA - a Victorian-era law that remains in force to this day. ${ }^{9}$ The 1967 Act demands, for instance, that two physicians have confirmed that the 'legitimate' conditions have been met, and that medical termination of pregnancy must occur within the confines of a clinical setting (Abortion Act, 1967, UK Government Legislation). Yet the 1967 Act has been surpassed by social and political change in England, such as the increased professionalisation of nursing and midwifery and particularly the fact that a significant number of abortions are now performed medically, rather than surgically. ${ }^{10}$ 'Illegitimate' abortions that are procured or performed outside the terms of the 1967 Act (e.g. self-sourcing medical abortion) remain a criminal offence under the 1861 OAPA, carrying a maximum sentence of life imprisonment. ${ }^{11}$

There is evidence to suggest that current care provision is not accessible or appropriate for all women in Britain, causing some women to procure medical abortion as a self-care strategy when 'legitimate' pathways provided through current legislation fails to meet their diverse needs. International telemedicine services, which usually prescribe medical abortion to women in countries with restrictive abortion laws, such as Northern Ireland, have received a number of online requests from women in Britain for at-home abortion care (Aiken et al., 2018). ${ }^{12}$

\footnotetext{
${ }^{6}$ The rights of a foetus can actually supersede those of the pregnant woman, even when there is a danger to her life. Media reports include the case of a teenager detained in a secure mental health unit against her will after her request for an abortion on mental health grounds and risk of suicide was rejected (Forster 2017). Another example is the case of a woman who became pregnant as a result of rape and had attempted suicide, yet was forced to undergo a caesarean section by law after her request for abortion was not granted (Holland and Mac Cormaic 2014). Ireland's restrictive abortion laws have even proven fatal for women in cases of non-viable pregnancies, such as the death of Savita Halappanavar. The above-mentioned cases demonstrate the inability of existing legislation to safeguard the lives of women. Clear choices are then made as to which life is deemed a priority by the state and those invested with the authority to act on behalf of the state (cf. Bacik 2015: 156).

${ }^{7}$ Later-term abortions are permitted if a woman's life is at risk or in cases of serious foetal disabilities.

${ }^{8}$ Whilst the NHS funded $98 \%$ of abortions carried out in $2016,70 \%$ of these terminations were outsourced to independent providers (Abortion Statistics, England and Wales: 2017, Department of Health and Social Care 2018).

${ }^{9}$ Sections 58 and 59 of the 1861 OAPA directly govern termination of pregnancy, and applies in England, Wales, and Northern Ireland. The 1967 Abortion Act does not apply in Northern Ireland. In addition, the Infant Life (Preservation) Act 1929 applies in England and Wales.

${ }^{10}$ Records in England and Wales state that $92 \%$ of abortions in 2015 were performed medically, and by the thirteenth week of pregnancy (British Medical Association 2017: 19). Medical abortion may not be suitable for all women who require a termination of pregnancy, in which case surgical abortion would be the appropriate form of care.

${ }^{11}$ Criminal sanctions can apply to any woman self-inducing an abortion, as well as anybody (including healthcare professionals) who participate in the carrying-out of abortion care, outside the terms of the 1967 Act.

12 'Women on Web' (WoW) is an online telemedicine organisation that arranges online consultations, medical abortion, and support over e-mail for (eligible) women in countries with restrictive abortion laws by proscribing a combination of mifepristone and misoprostol for use in the ninth week of pregnancy (see Sheldon 2016). Women in Britain do not have recourse to medical abortion via WoW as abortion care is legally available under the 1967 Abortion Act. In response to increasing requests for support from women in Britain, the organisation instituted a specific helpdesk to support women to explore sexual and reproductive healthcare options in their areas (Aiken et al. 2018). NB:
} 
Despite abortion care being lawfully available in Britain, personal and logistical barriers to access were cited as a major impetus for women requesting abortion pills online from telemedicine services (Aiken et al., 2018) as an alternative site of care and counselling. Procuring medical abortion is considered 'illegitimate,' and even subversive, because it directly 'challenges the traditional assumptions about service delivery requirements, the definition of a provider and the power dynamics related to providing abortion care' (Jelinska and Yanow, 2018: 87). While women in Britain are technically subverting current UK law by accessing abortion from alternative and extra-state sites of care, the British Pregnancy Advisory Service (2017) claim that many may be unaware of the legal consequences. ${ }^{13}$

The 1861 OAPA, which underpins current abortion legislation in the UK and Northern Ireland, has been described by Diana Johnson MP as 'the harshest criminal penalty of any country in Europe' (House of Commons Hansard, UK Parliament, 13 March 2017), which draws a comparison between Britain and Ireland as sharing a draconian and punitive stance on abortion and women's rights more broadly. In 2017 Johnson led attempts to partially decriminalise ${ }^{14}$ use of medical abortion outside the clinical domain, citing the availability of medical abortion online and how women procure telemedicine care because current abortion legislation is unable to meet their needs, but would be at risk of prosecution for doing so. ${ }^{15} \mathrm{It}$ is the $1861 \mathrm{OAPA}$ and Article 40.3.3 inserted into the Irish Constitution by its Eighth Amendment, two socio-legal relics, that are the subjects of current reform and targets of feminist activism in the UK (including Northern Ireland) and Ireland respectively. In this article we frame women themselves as having embedded (alternative or 'illegitimate') access to medical abortion in the social politics of current feminist movements to reform abortion legislation in Britain and Ireland, and as part of a historical trajectory where struggles for sexual and reproductive health-rights have provoked dynamic forms of bodily knowledge, activism, and autonomy.

These dynamic forms of feminist bodily knowledge were generated by the Women's Liberation Movement in Britain, a movement that emerged from the radical social movements of the 1960s and, from its inception, situated the body as a site of oppression and liberation. It is well established that women having control, knowledge and understanding of their own bodies was considered by feminists to be fundamental to freeing women from their subjugation (see, for example, Brooke, 2013; Davis, 2007; Nelson, 2015; O’Sullivan, 1987). This was because 'Women can only take charge of their lives if they can control their own reproduction' (Greenwood and King 1981: 168). Swells of feminist activism took place internationally as movements communicated with one another, increasingly enabled by the proliferation of feminist magazines and publishing houses (see Forster, 2016; Delap, 2016). Health and reproduction proved to be one of the issues that feminists communicated about most readily. Perhaps the most significant book that attained international status was focussed on bodily autonomy and knowledge: Our Bodies Ourselves, first published in the USA as a 193 page-pamphlet — and in 1973 published commercially under the title that would travel the world — has been examined by Kathy Davis (2007) to show how the text 'travelled' globally by encouraging women to draw upon their own experiences as a basis for knowledge. Davis contests that 'a politics of location identifies the grounds of historically specific differences and similarities among women in diverse and asymmetrical relations, creating alternative histories, knowledge practices, and possibilities for alliance' (2007: 10). It is through this that:

[i]nstead of being preoccupied with feminist history as a single story, multiple and diverse accounts of feminism in different places and at different points in time can be generated' and we can be encouraged to consider 'how feminism travels - that is, how feminist knowledge and knowledge practices move from place to place and are "translated" in different cultural locations' (Davis, 2007: 10).

Certainly, transatlantic currents shaped the British women's movement's engagement with feminist health issues (Segal, 1979: 168). At the same time, however, feminisms have been and are grounded in local contexts. As Margaretta Jolly (2012) has observed, the Women's Liberation Movement in the UK varied significantly by region and nation, shaped by the interactions facilitated by place. Jolly argues against making overarching generalisations about British feminisms, and points to the different networks that emerged in Northern Ireland, Scotland, England and Wales. Nonetheless, she suggests that 'living the life of feminist activism seems inevitably to challenge geographical belonging at some level' (Jolly, 2012: 145). This article argues that a lens on feminist activism around bodily autonomy and abortion politics should be both grounded in place and time while also seeking to push

The study by Aiken et al. (2018) coincided with reduced abortion care provision after Marie Stopes had to temporarily suspend certain services in England.

13 While few women in England and Wales are charged under the OAPA Act for procuring an 'illegitimate' abortion, Sally Sheldon (2015) argues that 'the fact that an archaic law is not enforced is not justification for retaining it.'

14 The British Medical Association (2017: 8) note that decriminalisation of abortion can involve a range of outcomes, with the most basic interpretation being a change in 'the default position so that instead of abortion being a crime for which there are some circumstances in which abortion is lawful, abortion would be lawful with some limited exceptions.'

${ }^{15}$ Johnson's 2017 'reproductive health (access to terminations) bill' passed the first reading, but the chance for a second reading and debate was lost due to the calling of the 2017 snap election. 
beyond them, examining how frustration with the status quo instigates the creation of alternative forms of care and encourages self-knowledge.

In both the contemporary movement in Ireland and Britain in the 1970s and 1980s new sites of communication developed in order to raise awareness of the different social, legal and political contexts in which women campaigned for their reproductive rights. The feminist magazine Spare Rib, founded in 1972, claimed that its attitude to health developed as much through individual women's own experiences, and through their desire to articulate what has happened to them, to communicate with other women and open up the possibility of collective self-help and self-definition' (O'Sullivan, 1988: 39). As the movement found, however, the emphasis on speaking from personal experience and the structuring of the movement in small groups frequently had the effect of privileging the voices of white, middle-class women (see Thomlinson, 2016). Attempts to give voice to women's diverse practices, and to recognise the experience of women outside Britain, were not always successful.

While at points British feminist publications were attentive to the work of their near neighbours in Ireland (Connolly, Bunting and Roisin 1982), magazines such as Spare Rib also faced charges of marginalising Irish women's struggles and practising exclusionary feminism. When Spare Rib was banned in Ireland by the Censorship of Publications Board in 1977, Irish feminists rallied to challenge the decision, while the magazine itself was perceived to have considered the ban as a 'morale booster for feminism' (Larragy, 1990: 39). The proximity between the two nations did not breed synchronicity: the Irish context was deeply informed by Catholic ideas, and the British Women's Liberation Movement was perceived to be narrow, making it 'almost impossible to discuss situations where the issues of choice were differently posed' (Larragy, 1990: 41). ${ }^{16}$

Irish feminists shared British feminists' interest in women's health: the first conference to be held in Dublin on women and health took place in May 1979 and was seen to break 'new ground with a public discussion of female sexuality,' (Wallsgrove et al., 1979: 11). The conference debated contraception, which had been outlawed by the Criminal Law Amendment Act 1935 and about which there was effective censorship as late as the 1960s (see Girvin, 2008; Ferriter, 2009). While British and Irish feminisms shared interests in the 1970s, there were also significant differences that arose from historical, cultural and social contexts; it is therefore productive to trace the significance and nuance of reproductive knowledges and activisms across temporal and geographical borders, and to examine the types of activism that different legislative conditions generate.

Feminists have long been active in asserting the importance of women's access to family planning methods, including abortion. The Women's Liberation Movement in Britain in the 1970s was no exception, with groups such as the National Abortion Campaign (NAC) emerging in the mid-1970s to defend the 1967 Abortion Act from attempts to impose limitations on it and to campaign for free abortion in demand (Scott and Noble, 1976). The activist work that was done around reproductive healthcare had implications beyond that which engaged with the law, however. Postwar feminists constructed new epistemologies of the body; as Nancy Tuana (2006) has asserted with reference to the American women's health movement, the movement was epistemological as well as liberatory. It was, Tuana suggests, 'an epistemological resistance movement' that sought to challenge the 'ignorance about women's health and women's bodies in order to critique and extricate women from oppressive systems often based on this ignorance, as well as creating liberatory knowledges' (2006: 2).

\section{ABORTION, REPRODUCTIVE RIGHTS AND THE PROVOCATION OF NEW TYPES OF KNOWLEDGE}

During the 1970s and 1980s the campaign for reproductive rights and abortion activism in Britain was an expression of and a demand for bodily autonomy, but it also opened up broader questions about power, knowledge, and access to information. In this period the NHS was seen to be both underfunded and hostile to women's empowerment; preserving the body as a site of ignorance and anxiety was considered a deliberate tactic to maintain professional authority by doctors. The local sites of care and self-knowledge production that the women's movement established were thus a reaction to the economic context of the NHS and the patriarchal context of the health profession. Local consciousness-raising groups were critical to the emergence and development of the women's movement in Britain. They played a crucial role in providing a space in which women could share their experiences in ways that reflected that the 'personal is political' (Bruley, 2013). Consciousnessraising groups were both a process for knowledge creation and a site for the development of political consciousness.

For women concerned with the development of feminist healthcare, self-knowledge was positioned as a defence against the vulnerabilities created by the unequal dynamic between doctor and patient; as an article published in Spare Rib in 1980 noted, 'When women talk about how they feel about going to the doctors, hospitals or clinics,

${ }^{16}$ For more on the Irish women's movement, see Connolly, L. (2003). The Irish Women's Movement: from Revolution to Devolution. London: Palgrave Macmillan.

(C) 2018 by Author/s 
they speak about feeling vulnerable and not knowing or understanding what is happening to them' (Brent Women's Centre, 1980: 19). In contrast to this, it was argued that spaces that encouraged feminist self-help both increased women's confidence and allowed them greater control over reproduction. 'Self-help has, universally, helped to dispel myths for a lot of women', observed an article in Spare Rib in 1974, dispelling 'the mysterious functioning of our bodies that most doctors and gynaecologists would have us believe' (Spare Rib, 1974: 19). Feminists who worked in women's health care in the 1980s reiterated this emphasis on information and knowledge dispersal. 'If people have knowledge about their health... then they can choose to exercise control over their health' suggested Christine Webb in 1986, whereas, deprived of this information 'they are forced to remain patients in the literal sense - passive receivers of what others think is good for them' [emphasis in original] (Webb, 1986: 183). All too often, Webb argued, men comprised this 'other', and considered 'a person principally as a disordered body whose malfunctions are isolated from the rest of social life, with its prescriptions of appropriate roles and behaviour for women and men.' Feminist self-knowledge came to play an important role in addressing and compensating for services that did not meet women's needs or view them in the context of social life. It was a 'radical statement' for women's health to be asserted as 'our business above all, that our bodies are our own to use as we please, and that our interest in all parts of ourselves is legitimate,' claimed a 1981 feminist pamphlet that described the process of self-examination. This statement of bodily autonomy was 'a part of the struggle for women's liberation' (Laws, 1981: 5).

This 1981 pamphlet, Down There: an Illustrated Guide to Self-Exam, demonstrates the multiple sites of activism that were established in order to reclaim authority over women's own reproduction: as well as recommending involvement in a women's liberation group ('the best way to learn self-exam is within a women's liberation group - either a general or consciousness-raising group or one specifically focussed on women's health' 1981: 6) it also included a reading list and advised that speculums could be purchased at Sisterwrite, a feminist bookshop in Islington, North London (Laws, 1981: 28). Bookshops occupied a significant place in the Women's Liberation Movement (Delap, 2016), and here Sisterwrite provided both the site and the tools for accessing new bodily knowledges. The focus on the body and reproduction created new channels for the sharing of techniques, knowledge and information. Again, this was underwritten by a conviction that the development of knowledge not extracted from or expressed by medical professionals was a direct challenge to their epistemic authority. 'Most doctors don't seem to like their patients to know anything about their bodies' the pamphlet observed, 'and are especially threatened by women who make informed demands' (Laws, 1981: 23). For women seeking reproductive autonomy, '(s)haring knowledge is...sharing power' (Webb, 1986: 183).

Health and reproduction provoked locally-grounded knowledges, raising awareness of the sympathies and politics of local councils. A 1980 article in Spare Rib noted the willingness of Brent Community Health Council to support the use of their facilities to host a women and health course; the article noted that Brent, an area of North West London, 'has already had severe cut backs in its health services' and that the area was a site of 'over-crowding, poor housing, huge council estates with few facilities and high unemployment' (Brent Women's Centre, 1980: 19). The knowledges provoked by health activism extended beyond the individual body and into an understanding of the contours of civic life. This knowledge of the community was attentive to the ways that women's lives were structured by intersecting oppressions. The pamphlet promoting the Northern Women's Health Conference, held at Manchester Polytechnic in July 1985, noted that 'obtaining effective health information, advice, treatment and care can be a problem for all women but particularly if we are black, disabled or elderly' (Northern Women's Health Conference, 1985: 2). The conference, it noted, 'takes place against a background of rising unemployment and cuts in local authority and NHS spending, placing an even greater burden on women's lives' (Northern Women's Health Conference, 1985: 2). Health activism, therefore, required that women undertook analytical and empathetic readings of how national policy and politics affected women's bodies, particularly bodies on the margins.

As with the campaign to repeal the Eighth Amendment in Ireland, much reproductive activism in Britain organised around engaging with legislation and law makers. The Abortion Law Reform Association (ALRA) was formed in 1936 and played an important role in the campaign for the 1967 Abortion Act; once it was achieved, the ALRA shifted its priorities towards education, and the NAC instead came to the 'forefront of abortion advocacy' (Brooke 2013: 202). The NAC was formed in 1975 in direct response to threatened legal changes and worked to defend the Abortion Act from legislative attempts to amend and limit it (Scott and Noble, 1976: 20). The organisation was successful in mobilising support: its first conference was attended by 900 people. The conference was, however, criticised for focussing on internal structural issues rather than 'discussion of the current political situation and the types of restrictive legislation which might be proposed in the next parliamentary session' [emphasis in original] (Scott and Noble, 1976: 20), demonstrating the enduring focus on defending 'legitimate' forms of reproductive health care. Like the March for Choice in Dublin in 2016 (discussed below), the 1970s saw support for abortion rights draw people to London's streets. In the summer of 1975, twenty thousand people demonstrated in support of the 1967 Act (Brooke, 2013: 202). Activism around reproductive rights sought to be 
outward looking, visible and proactive, raising stark similarities with the campaign led by Irish feminist movements to 'Repeal the Eighth.'

\section{RISE AND REPEAL: SELF-ADMINISTERING BODILY AUTONOMY THROUGH SOCIAL PROTEST}

Reproductive rights activities staged in 2016 offer a point of departure to critique the contemporary social politics of abortion in Ireland, though it is important to note that the 1983 Referendum did not cause activism to stagnate. ${ }^{17}$ What is important is how social protests held across Ireland in 2016 challenged the hegemony of the state to withhold abortion care from women in Ireland, illustrating how types of bodily epistemologies emerged from historically situated narratives of resistance. On 24 September 2016, approximately twenty thousand people joined the fifth March for Choice in the streets of Dublin, an annual public demonstration demanding free, safe and legal access to abortion care in Ireland. The Abortion Rights Campaign (n.d.), which funded and organised the rally, is a leading protagonist of action calling for the Irish State to 'ensure the health and rights of women in pregnancy are protected in line with international human rights standards.'

One notable aspect of the 2016 demonstration was the foregrounding of historical events in its protest discourse. The vocabulary and evocation of the female 'body' as a site of control, resistance, and autonomy were deliberately entrenched in Ireland's social and political history to provoke public reflections between occupations of the past and present. ${ }^{18}$ The body and the state as dual sites of imperial power had long been a subject of critical dissent by Irish feminists. 'By imperialism,' the group Women Against Imperialism explained in Spare Rib in 1989, 'we mean those forces which deny us control over our own lives, over our bodies as women, as of our country as an independent state' (Women Against Imperialism, 1989: 57). 'Imperialism', they wrote, 'sustains a maledominated society, so that women are always defined in relation to men, and are oppressed by anti-woman laws denying our right to choice [sic] in matters of sexuality, family, reproduction and welfare entitlements.' Imperialism, it was contested, was multivalent in Irish women's lives. Anthropologist Angela Martin has argued that that 'Irish anti-abortion rhetoric' constitutes a 'violent form of nationalist identity politics,' and that the 'correspondence between the nation-state and gendered bodies materially mediates the ways in which feminine bodies are constructed, disciplined and experienced' (2000: 66). Historical continuities and discontinuities emerge between the pursuit of autonomy for the Irish population or body politic against British imperial rule vis-à-vis the governance of individual women's bodies put forward by the Irish state (inspired by Catholicism) in the present day. ${ }^{19}$

The 2016 'March for Choice' ran with the tagline 'rise and repeal' as a deliberate provocation and reflection on the centenary of the Easter Rising in 1916, when Irish republicans sought to forcefully dis-incorporate Ireland from British imperial domination and proclaim an independent state (Figure 1). The Easter rebellion was a bold pursuit of self-governance that was largely enacted in Dublin, and its 1916 proclamation announced 'the right of the people of Ireland to the ownership of Ireland, and to the unfettered control of Irish destinies.' The Easter Rebellion was quashed in a heavy and barbarous response by British occupying forces (as was anticipated by the protagonists), but was nonetheless instrumental in mobilising public support for Irish self-governance. What is important is how the rhetoric surrounding early twentieth-century nationalism in Ireland was appropriated in the context of reproductive politics in 2016, as the fifth 'March for Choice' articulated the right of women in Ireland to bodily autonomy and control (Figure 2). This interplay between past and present was made clear in the language employed by the Abortion Rights Campaign (2016) on their homepage, in what reads as a proclamation against an ongoing occupation imposed over women's bodies and their right to reproductive justice by the Irish State:

The Easter Rising sought Sovereignty and self-determination for Ireland. Today, we seek the same control over our own bodies. No longer will the Irish State force us to self-administer health care by taking abortion pills (risking a fourteen year jail term), or spend thousands of euro travelling secretly to England. This year we, the women of Ireland, with the support of all those who care about equality and human rights, are self administering our independence. (https://www.abortionrightscampaign.ie/2016/08/02/riseand-repeal-march-for-choice-2016, 2 August 2016. [Emphasis added])

\footnotetext{
17 See for instance Mullaly (2005).

${ }_{18}$ While we focus on the historical continuities between the discourse of the Easter Rising of 1916 and the 2016 'rise and repeal' demonstration, it is important to note that reproductive politics in Ireland evoke several historical controversies that are beyond the scope of this article. This includes the Mother and Baby Homes (read: homes for unmarried women to birth 'illegitimate' children) that were managed by the religious establishments in Ireland (both Catholic and Protestant), which have been the focus of recent political scrutiny and inquiry.

${ }^{19}$ See also Fletcher (2001) who critiques the various ways in which Irish colonial history has been deployed in activist discourse to exclude and enable access to abortion care.
} 


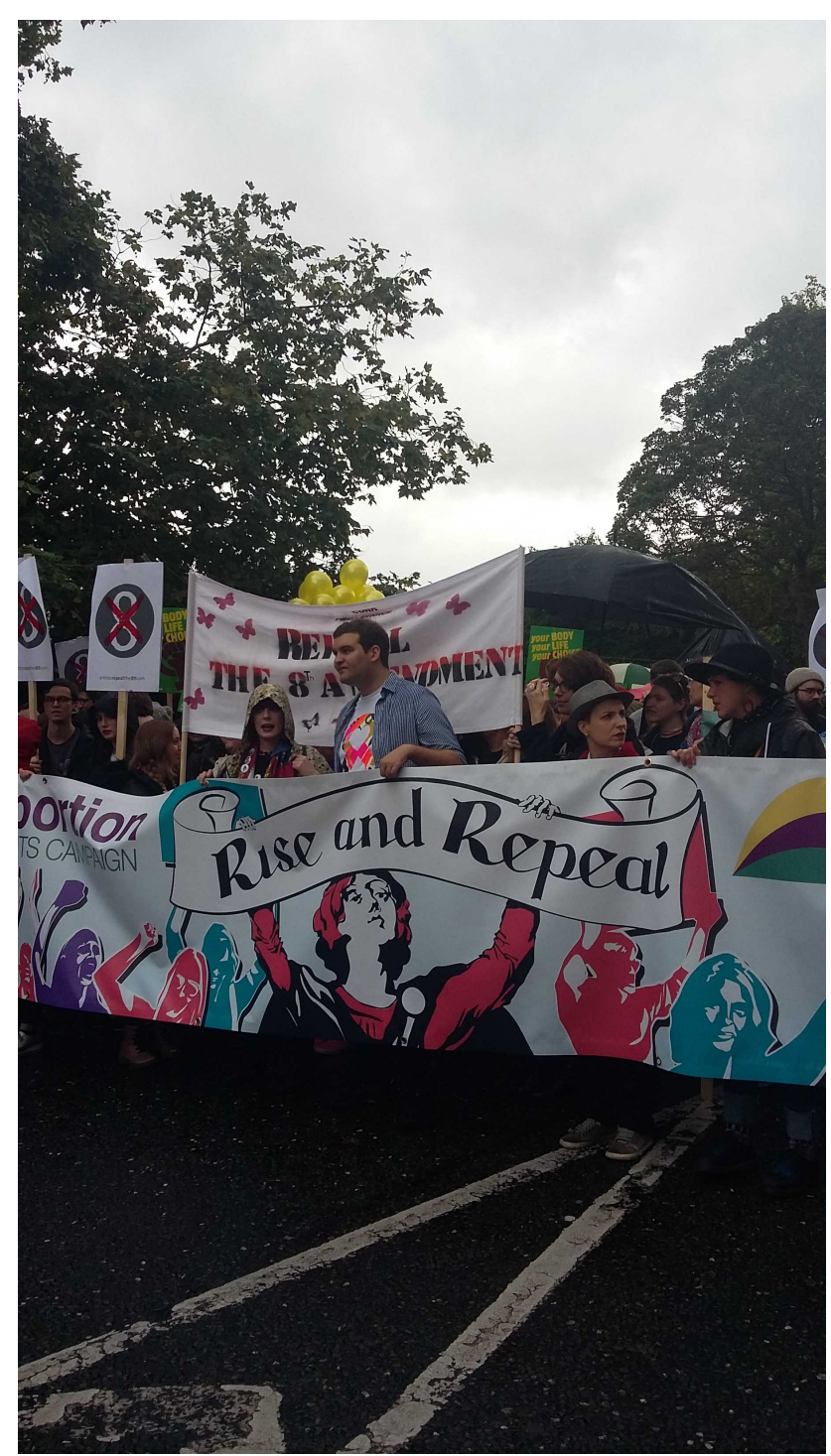

Figure 1. Activists holding the 'rise and repeal' promotional material produced by the Abortion Rights Campaign at Dublin's 2016 March for Choice, photograph by Ben Kasstan

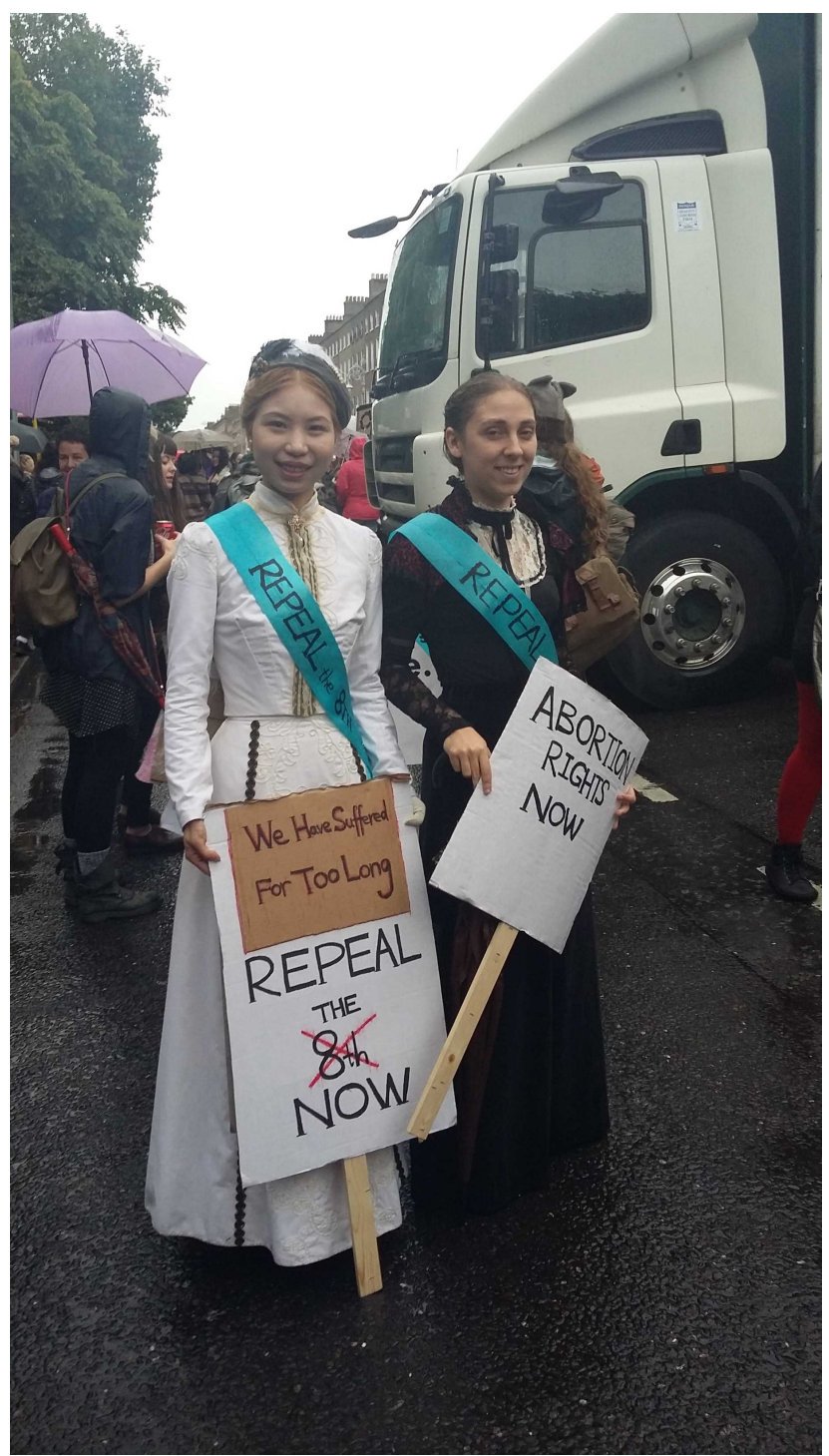

Figure 2. Activists dressed in twentieth century period dress at Dublin's 2016 March for Choice, photograph by Ben Kasstan

The centennial rhetoric of Irish self-governance was pervasive in almost all areas of the demonstration. The 'March for Choice' protestors turned out en masse from across Ireland despite inclement weather and, more noteworthy, a public transport strike that prompted the organisers to field a communal campaign of 'carpool for choice.' Featuring an image of two women drivers dressed in early twentieth century garments (Figure 3), the 'carpool for choice' campaign teased out historical continuities with the Irish struggle for independence that was heavily reliant on cultivating public support and camaraderie. The task of representing the nation state and of signifying the values of the Republic has fallen disproportionately upon women (Martin, 2000), demonstrating how the campaign to 'Repeal the Eighth' Amendment plays with and subverts this tradition of women's visibility in the body politic. 


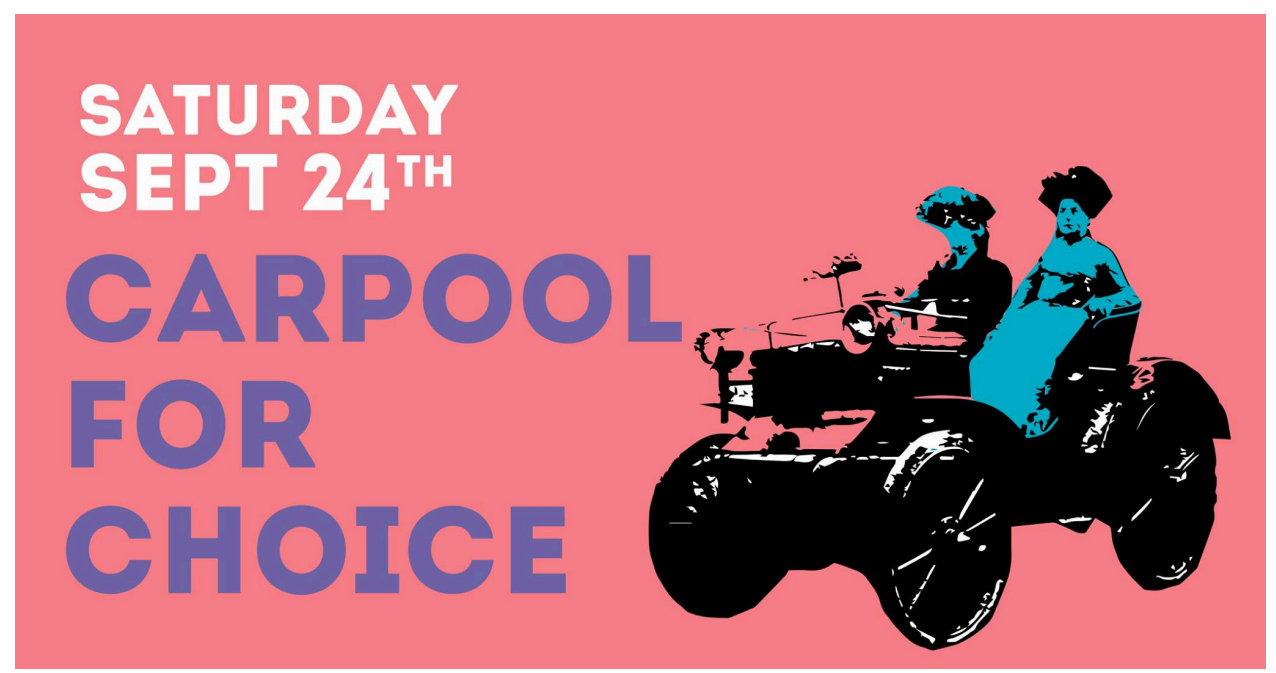

Figure 3. 'Carpool for choice' promotional material (Abortion Rights Campaign)

Protesters massed and mobilised at 2pm outside Dublin's Garden of Remembrance and Parnell Square East: the former being a memorial to those who lost their lives during the 'cause of Irish freedom,' and the latter being a city centre road dedicated to Charles Stewart Parnell — one of the formative architects and protagonists of Irish home rule during the nineteenth century. Many of the speeches, placards, and statements expressed by demonstrators were explicit in echoing the historical rhetoric tied to the Easter Rebellion, with one speaker announcing, 'this is our rising' - thus framing the 2016 demonstration as a proclamation.

The rhetoric of the 2016 'rising' should be interpreted as more than the marshalling of a metaphor and is placed in continuity with defining historical struggles of Irish self-governance sanctioned through the body and gender. ${ }^{20}$ The discourse of the 'rise and repeal' protest is intentional and demonstrates how women were dis-incorporating themselves from oppressive and forceful state legislation by self-administering their right to bodily autonomy. ${ }^{21}$ The call to 'rise and repeal' reflects a collective appropriation of historical knowledge and political narratives in contemporary social protest to make visible the continuing struggles for equitable rights among all citizens in Ireland. More broadly, anthropological studies have described how the use of historically politicised language in social protests can 'draw attention to the past to champion alternative futures' (Knight, 2015: 242). Similarly, abortion rights activists in Dublin mobilised the rhetoric of twentieth century Irish nationalism and rebellion to lay claim to a future in which reproductive and human rights are protected, reflecting the ambitions of British feminists in the 1970s and 1980s.

Statements chanted by individual activists articulated how reproductive and abortion politics are entangled in the union between 'church and state' in Ireland, with some demonstrators shouting 'keep your rosaries off our ovaries' and 'I demand a separation between vagina and state' (Figure 4). The Irish state and Catholic establishment were then cast as synonymous occupiers of the female body, and more specifically, women's reproductive rights. In so doing, the abortion activists exemplify how slogans aired in public have the capacity to 'incite collective victimhood and solidarity in opposition to faceless systems and help promote the priorities of everyday people as they struggle against hegemonic political and economic policies and practices' (Knight, 2015: 242). ${ }^{22}$

\footnotetext{
${ }^{20}$ Women were actively engaged in the Irish Rising and revolution but their contributions were not acknowledged as equal to male combatants (Coleman, 2017), thus the feminist rhetoric of the 'rise and repeal' protest articulated the (individual) female body's enduring struggle within the body politic, long after the twentieth century quest for independence.

${ }^{21} \mathrm{It}$ is important to add that Ireland has long been personified in the feminine form, imagining the body politic as being in need of (male Irish) possession and re-possession in case of British occupation (see Butler Cullingford, 1990) — a rhetorical device that has arguably impregnated the politics of abortion and control of women's bodies in Ireland (Human Rights in Ireland, 2013). What is interesting is how the historical rhetoric surrounding the fifth March for Choice simultaneously engages and resists this imagery by calling for women oppose state control by calling on women to self-administer their bodily autonomy.

${ }^{22}$ Daniel Knight (2015) examines the circulation of historical slogans and metaphors in the context of resistance to Greek austerity, which offers an ethnographic comparison to the 2016 March for Choice.
} 


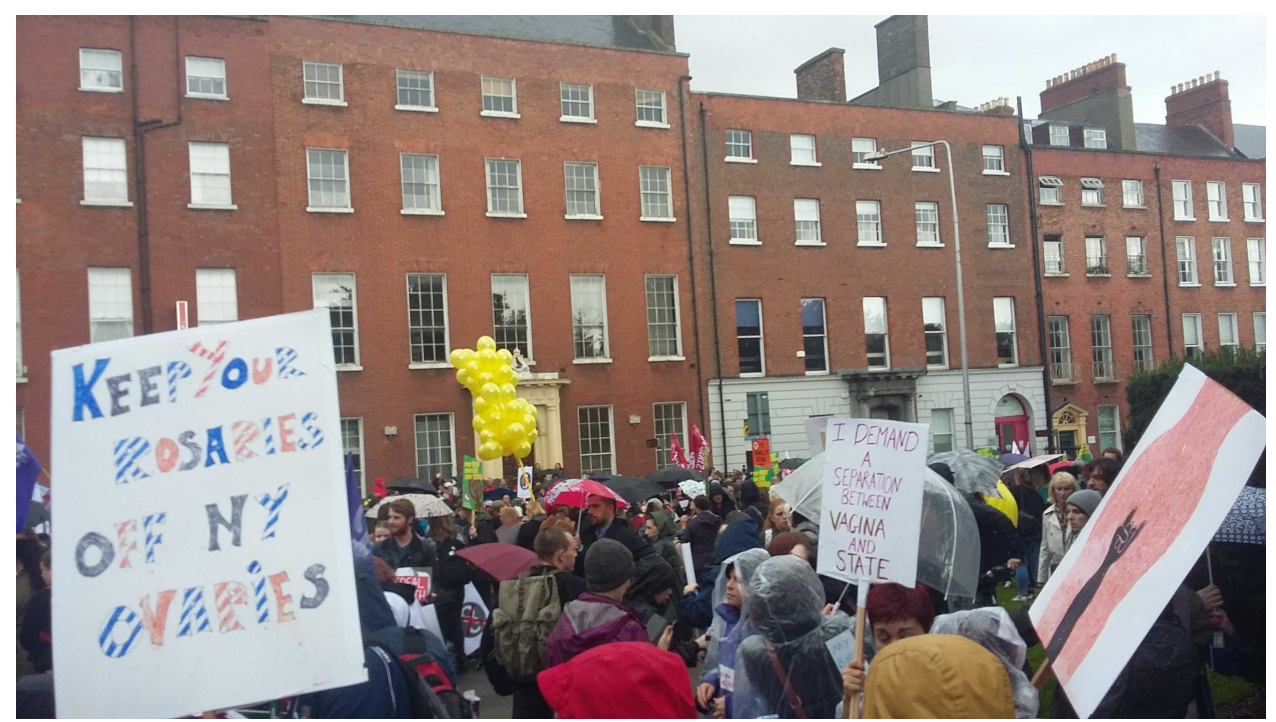

Figure 4. Activists at Dublin's 2016 March for Choice, photograph by Ben Kasstan

Two Women Travel

@TwoWomenTravel

\section{Following}

\section{Forced 2 leave Ireland, @EndaKennyTD joined \\ by more Irish in waiting room, waiting for our loved ones \#twowomentravel}

Two Women Travel

@TwoWomenTravel

\section{We stand in solidarity with all women exiled by @EndaKennyTD, his predecessors, and apologists. \#twowomentravel}

Figures $5 \& 6$. Tweets by @TwoWomenTravel describing the experience of being 'forced' and 'exiled' to access extra-state abortion care

\section{ABORTION AND CONFRONTATION, EXILE AND EVASION}

The act of travelling abroad to terminate a pregnancy has been described as 'abortion tourism' (see Bloomer and O'Dowd, 2014). Similarly, the term 'reproductive tourism' is often used to frame extra-state pursuits of fertility treatment, yet conflicts radically with the actual desperation and stresses experienced by people engaging in IVFrelated mobilities (Inhorn, 2018). For this reason, Marcia Inhorn and Pasquale Patrizio (2009: 905) have described how 'reproductive exile' is a more appropriate conceptual reference because, in most cases, people describe 'how they feel "forced" to leave their home countries to access safe, effective, affordable and legal infertility care.' Against this backdrop we challenge conceptual references of abortion 'tourism' (Bloomer and O'Dowd, 2014) and 'travel' on the basis that women engaging in social protest in Ireland represent themselves as being forced and exiled to leave Ireland in order to access extra-state and alternative sites of abortion care (Figures 5 and 6). The image of 'travelling' abroad for abortion care obscures the fact that extra-state care can be prohibitively expensive for some women, traumatic, emotionally and physically painful, and remains enshrouded by shame, secrecy, stigma and lack of emotional support from family and friends. Moreover, due to lack of knowledge about the legal status of reproductive exile and fear of possible consequences, women can be reluctant and cautious about accessing post-abortion care upon return in Ireland if complications arise. ${ }^{23}$

23 See Manchester Metropolitan University News 2017. 
Specific to the Irish context is the fact that the Irish Constitution enshrines a 'structural tolerance and expectation of abortion travel' (de Londras and Enright, 2018: 8). Women in Ireland, we argue, are literally exiled when they feel compelled to access extra-state abortion care rather than continue a pregnancy to term against their wish. The constitutional expectation of reproductive exile in Ireland is an assault on human rights because it actually 'contradicts the foundation on which human rights law stands - that states have an obligation to respect, protect, and fulfil human rights within their own borders' (cf. Zampas, 2017: 34). ${ }^{24}$

Reproductive rights activists estimate that, on average, nine women are exiled from Ireland each day to access extra-state abortion care at their own cost (mainly in England), amounting to approximately 4,000 reproductive exiles per year (Coalition to Repeal the Eighth n.d.). Two women crossing the Irish Sea to access abortion services in August 2016 launched a Twitter account using the handle '@TwoWomenTravel' to document their repro-exile in real time through Tweets of 140 characters. The two women had frequently tagged Enda Kenny, the then Taoiseach ('Chief' or Head of Government) in their Tweets to portray the realities of being exiled to extra-state sites of care. The series of Tweets articulated the anxieties of the two women who framed themselves as being 'forced' to leave their home country in a struggle for bodily autonomy (Figures 5 and 6). Rather than viewing @ TwoWomenTravel in isolation, we interpret them and their documented struggle for bodily autonomy as a reflection of the broader rallying of public support for abortion rights in Ireland that has led up to the 2018 Referendum. It is important to note that the overall rate of reproductive exiles to England have reduced significantly in recent years, halving between the years 2001 and 2016, which is likely due to eligible women remaining at home and subverting Irish law by accessing safe medical abortion and appropriate counseling online via telemedicine services (Sheldon, 2016).

\section{REPRODUCTIVE ACTIVISM AND THE SUBVERSION OF CONTROL}

Telemedicine services are, as mentioned, an 'illegitimate' site of abortion care under British and Irish laws yet they offer eligible women in contexts of restrictive abortion legislation a more compassionate and affordable option to reproductive exile. More critically, they offer eligible women a lifeline by enabling them to avoid dangerous techniques of inducing a miscarriage (such as perforation techniques or ingesting noxious substances), which remain a reality for some women in Ireland (Gentleman, 2015; Sheldon, 2016). Medical abortion prescribed to women in Ireland by WoW is reported to be highly effective, with low reported prevalence of adverse reactions and, more importantly, almost all women follow the advice of WoW by seeking medical attention when experiencing potential complications (Aiken et al., 2017). Thus, women in Ireland subvert restrictive abortion laws with a high degree of competence, demonstrating how women trust themselves to exercise bodily autonomy as part of a responsible process of reproductive decision-making. That being said some women who subvert legislation by procuring medical abortion do not feel they can safely disclose their experiences of self-care to healthcare professionals (see Sheldon, 2016: 95), which reflects the legal anxieties women feel about accessing postabortion care in Ireland after reproductive exile.

Whilst women procuring medical abortion online routinely subvert Irish law, access can be precarious as Irish Customs and Excise Officers have the authority to seize abortion pills, compelling women to collect the deliveries at a post office or designated address in Northern Ireland (see Fletcher, 2014:11). Irish Customs and Excise Officers confiscated 1017 abortion pill deliveries in 2014, more than double those seized in the previous year (Abortion Rights Campaign, n.d.). Leo Varadkar, the current Taoiseach of Ireland and former medic, linked the reality of reproductive exile as well as the 'illegitimate' yet widespread use of medical abortion among women in Ireland as notable reasons that led to the cabinet decision to hold a referendum in 2018:

We know that thousands of Irish women - women from every single county in Ireland - go abroad for abortions every year. We know that many women are obtaining abortion pills through the post to end their pregnancies, without any medical support, or counselling, or supervision. So, we already have abortion in Ireland but it is unsafe, unregulated and unlawful. We cannot continue to export our problems and import our solutions. (Leo Varadkar, Prime Minister of Ireland, reported in The Irish Times on 30 January 2018 [emphasis added])

The fact that 'illegitimate' abortion services were known to be more widely sought than what could be 'legitimately' provided by the Irish state within the confines of the Constitution can then be considered as a significant impetus for the Taoiseach's support for reform. In contexts of restrictive abortion laws more broadly,

\footnotetext{
${ }^{24}$ Women in Ireland who hold precarious residency statuses (such as asylum seekers) can experience limitations on international mobility, preventing timely access to extra-state abortion care (see Side 2016). The financial cost of abortion care can rise considerably when performed after twenty weeks of gestation, which is an issue for women experiencing bureaucratic delays in receiving a visa to enter the UK (see Duffy and Pierson n.d.).
}

(C) 2018 by Author/s 
such as Poland, women have mobilised protest logics to subvert and 'beat the system' by procuring abortions 'illegitimately" - either by sourcing misoprostol online or via the "white coat" underground' provided by healthcare professionals operating clandestinely (Mishtal, 2017: 240). However, Joanna Mishtal has argued that reform of restrictive abortion laws in Poland is unlikely to be achieved through 'quiet and individual dissent without the political act of visibility and public engagement' (2017: 240). The case of Ireland demonstrates how opportunities for re-envisaging the constitutional and legal status-position of abortion care were made possible by feminist activism around self-care, with individual acts of reproductive exile and subversion of current laws entrenched in sustained and prominent social protests.

\section{CONCLUSION: ABORTION AND REPRODUCTUVE RIGHTS BRING NEW TYPES OF COMMUNITY INTO BEING}

Both the women's movement in the 1970s and 1980s in Britain and the contemporary campaign for legislative reform in Ireland have made use of international and diasporic connections. In contemporary Ireland pregnant women's transition into exile has been leveraged to raise awareness of the international dynamics of the existing legislation; comparisons with other countries have also been used to highlight the regressive nature of the current laws. Martin (2000: 71) notes that Ireland's nationalist discourses draw upon gendered issues to emphasise its 'alterity' in an increasingly interconnected Europe; feminists point to this alterity for other ends, using it to highlight the desperation of the women forced into exile. While some internationalist elements of feminism have been critiqued as obscuring or eliding power differentials and difference (see Braidotti, 1992) understanding the approaches of other nations to the governance of the female body has been a critical part of feminist praxis. Considering the ways that the Irish campaign made use of similar discourses around health, rights, care and autonomy to those used in the 1970s and 1980s by the British women's movement demonstrates the flexibility and utility of these ideas. Feminist campaigns attempt to decentre and reclaim the authority exacted over women's bodies and to raise consciousness of the damaging consequences of derisory state health care and discriminatory legislation.

Just as the movement of the 1970s and 1980s used feminist magazines to communicate with an engaged audience, the Repeal movement in Ireland used social media to raise awareness of reproductive exile as a lived reality of restrictive and unjust legislation. In so doing abortion care activists in the Irish diaspora re-appropriated the narrative of abortion 'travel' to promote electoral participation in the 2018 Referendum. The London-Irish Abortion Rights Campaign (n.d.), a grassroots movement to 'bring people in London together to campaign repeal of the Eighth Amendment from the Irish Constitution and for the decriminalization of abortion in Northern Ireland,' launched hometovote.com (n.d.) in 2017 as a strategy to 'summon vote-eligible Irish people living abroad.' The rhetoric of 'summoning' Irish emigrants 'home' by a grassroots movement is again striking because it imposed a moral and civic obligation on the body politic, and raises historical continuities with the language surrounding the 1916 Uprising, by re-presenting a mutual and enduring ownership of Irish people over Ireland and vice versa. Using social media as a 'global call' for vote-eligible Irish citizens was inspired by the landslide 2015 Referendum result in favour of same-sex marriage, which rallied emigrants from around the world to 'vote yes for a fairer Ireland.' In both of these examples, social media (particularly Twitter and Instagram) were cultivated as a phenomenally powerful resource in resistance to gender and marital inequalities.

Our focus on the dynamics of abortion activism in Britain and Ireland can be situated in broader discussions of how feminist movements have historically spearheaded techniques of self-care, and in so doing, provoked the state to better meet the needs of women. In tracing the role of pregnancy testing as a 'feminist technology' in the 1970s Women's Liberation Movement, Jesse Olszynko-Gryn has argued that 'British feminists framed pregnancy testing as a more efficient and sympathetic alternative to the inadequate N.H.S. as they pushed for reform. They appropriated a medical technology, bringing it into the domestic sphere and endowing it with the politics of the movement' (2017:19). Similarly, we have cast the subversive and 'illegitimate' procurement of medial abortion among women in Britain and Ireland as being the object of opportunity for legislative reform and constitutional change, provoking responses from politicians. Women in Britain face the threat, in theory, of life imprisonment by procuring medical abortion, and women in Ireland attending the 2016 March for Choice publicly proclaimed how they felt 'forced' to self-administer medical abortion despite the risk of a fourteen-year jail term. We argue how, on both sides of the Irish Sea, it is the women themselves that have situated medical abortion in the social politics of feminist movements to champion legislative and constitutional reform. Medical abortion is embedded in feminist struggles for reproductive rights and demands for equitable and accessible public health services, which is, as Varadkar made clear, a known subversion. What emerges are situations where the 'illegitimate' could, following the landslide 2018 Referendum result, be brought into the realm of state control and guardianship, and in Britain, potentially re-envisage abortion legislation to enable women to use medical abortion from the comfort and convenience of their own homes. Reproductive rebellions over time have led women to rise for 'repeal' in 
Dublin and produced 'liberatory knowledges' within British feminist movements, which, in each of these contexts, have been generative of new modes of community, sites of activism, and political responsiveness.

The reproductive rebellions we have observed in Britain and Ireland are historically contiguous, and whilst enacted at different points in time and place, share a common strategy in attempting to position women's bodily autonomy and knowledge as an enduring site of activism within the body politic. Our interdisciplinary approach illustrates how feminist encounters in the medical humanities can chart the continuities and discontinuities of abortion activism and rebelliousness in two intimately connected contexts during periods of significant change.

\section{REFERENCES}

Abortion Rights Campaign. (n.d.). About ARC. Available at: https://www.abortionrightscampaign.ie/about-arc (Accessed 4 March 2018)

Abortion Rights Campaign. (2016). Rise and repeal march for choice. Available at: https://www.abortionrightscampaign.ie/about-arc (Accessed 4 March 2018)

Abortion Statistics, England and Wales: 2017. (2018). Department of Health \& Social Care. https://assets.publishing.service.gov.uk/government/uploads/system/uploads/attachment_data/file/71418 3/2017_Abortion_Statistics_Commentary.pdf (Accessed 18 August 2018)

Aiken, A. R. A., Digol, I., Trussell, J. and Gomperts, R. (2017). Self reported outcomes and adverse reactions events after medical abortion through online telemedicine: population based study in the Republic of Ireland and Northern Ireland. British Medical Journal, 357-j2011. https://doi.org/10.1136/bmj.j2011

Aiken, A. R. A., Guthrie, K. A., Schellekens, M., Trussell, J. and Gomperts. R. (2018). Barriers to accessing abortion services and perspectives on using mifepristone and misoprostol at home in Great Britain. Contraception, 97, 177-183. https://doi.org/10.1016/j.contraception.2017.09.003

Bacik, I. (2015). A feminist review of the law on abortion in Ireland, in C. Fischer and M. McAuliffe (eds.), Irish feminisms: past, present, and future (pp. 147-168). Dublin: Arlen House.

Berer, M. (2013). Termination of pregnancy as emergency obstetric care: The interpretation of Catholic health policy and the consequences for pregnant women. Reproductive Health Matters, 21(41), 9-17. https:// doi.org/10.1016/S0968-8080(13)41711-1

Bloomer, F. and O'Dowd, K. (2014). Restricted access to abortion in the Republic of Ireland and Northern Ireland: Exploring abortion tourism and barriers to legal reform. Culture, Health \& Sexuality, 16(4), 366-380. https://doi.org/10.1080/13691058.2014.886724

Brent Women's Centre. (1980). Women \& Health: How to run a health course. Spare Rib, 94, 19-22.

British Medical Association. (2017). Decriminalisation of abortion: a discussion paper from the BMA. Available at: https://www.bma.org.uk/advice/employment/ethics/ethics-a-to-z/abortion (Accessed 8 April 2018)

British Pregnancy Advisory Service. (2017). Women in Great Britain putting themselves at risk of life imprisonment as use of illegal abortion medication rises. Available at: https://www.bpas.org/about-our-charity/press-office/pressreleases/women-in-great-britain-putting-themselves-at-risk-of-life-imprisonment-as-use-of-illegal-abortionmedication-rises (Accessed 3 March 2018)

Brooke, S. (2013). Sexual Politics: Sexuality, Family Planning, and the British Left from 1880 to the Present Day. Oxford: Oxford University Press.

Bruley, S. (2013). Consciousness-Raising in Clapham: Women's Liberation as 'Lived Experience' in South London in the 1970s. Women's History Review, 22(5), 717-738. https:// doi.org/10.1080/09612025.2013.769378

Coalition to Repeal the Eighth. (n.d.). Abortion in Ireland - the current situation. Available at: https:/ /www.repealeight.ie/abortion-in-ireland-today (Accessed 29 March 2018)

Coleman, M. (2017). Compensating Irish Female Revolutionaries. Women's History Review, 26(6), 915-934. https://doi.org/10.1080/09612025.2016.1237002

Connolly, A., Bunting, S. and Boyd, R. (1982). A Decade of Struggle: Irish Women's Liberation. Spare Rib, 118, 68.

Connolly, L. (2003). The Irish Women's Movement: from Revolution to Devolution. London: Palgrave Macmillan.

Cullingford, E. B. (1990). 'Thinking of her ... as ... Ireland': Yeats, Pearse and Heaney. Textual Practice, 4(1), 1-21. https://doi.org/10.1080/09502369008582073

Davis, K. (2007). The Making of Our Bodies, Ourselves: How Feminism Travels Across Borders, Durham, NC: Duke University Press. https://doi.org/10.1215/9780822390251

de Londras, F. (2015). Constitutionalizing fetal rights: A salutary tale from Ireland. Michigan Journal of Gender \& Law, 22(2), 243-289. https://doi.org/10.2139/ssm.2600907

de Londras, F. and Enright, M. (2018). Repealing the 8th: Reforming Irish abortion law. Bristol: Policy Press. https://doi.org/10.1332/9781447347545 
Delap, L. (2016). Feminist bookshops, reading cultures and the Women's Liberation Movement in Great Britain, c. 1974-2000. History Workshop Journal, 81(1), 171-196. https://doi.org/10.1093/hwj/dbw002

Department of Health. (2017). Third annual report of notifications in accordance with the Protection of Life During Pregnancy Act 2013 laid before the Houses of the Oireachtas. Available at: https://health.gov.ie/blog/press-release/third-annual-report-of-notifications-in-accordance-with-theprotection-of-life-during-pregnancy-act-2013-laid-before-the-houses-of-the-oireachtas (Accessed 15 July 2018)

Duffy, D. and Pierson, C. (n.d.). Abortion in Ireland and inequality. Manchester Metropolitan University. Available at: http://rszarf.ips.uw.edu.pl/inequality/abortion_inequality.pdf (Accessed 3 March 2018).

Enright, M., Conway, V., de Londras, F., Donnelly, M., Fletcher, R., McDonnell, N., McGuinness, S., Murray, C., Ring, S. and uí Chonnachtaigh, S. (2015). Abortion law reform in Ireland: A model for change. Feminists@law, 5(1). http://journals.kent.ac.uk/index.php/feministsatlaw/article/view/173/631

European Court of Human Rights. (2010). Case of A, B, and C v Ireland. Available at: https://www.dfa.ie/media/dfa/alldfawebsitemedia/ourrolesandpolicies/internationallaw/echr-a-b-and-c-vsireland-2010.pdf (Accessed 25 July 2018)

Ferriter, F. (2009). Occasions of Sin: Sex and Society in Modern Ireland. London: Profile Books. https://doi.org/10.1016/S0968-8080(14)44818-3

Fletcher, R. (2001). Post-colonial fragments: Representations of abortion in Irish law and politics. Journal of Law and Society, 28(4), 568-589. https://doi.org/10.1111/1467-6478.00203

Fletcher, R. (2014). Contesting the cruel treatment of abortion-seeking women. Reproductive Health Matters, 22(44), $10-21$.

Forster, K. (2017). Irish teenager seeking abortion 'detained in psychiatric unit.' The Independent. Available at: http://www.independent.co.uk/news/health/abortion-detained-psychiatric-unit-ireland-mental-health-actgirl-sectioned-pregnant-a7789856.html (Accessed 13 October 2017)

Forster, L. (2016). Spreading the Word: feminist print cultures and the Women's Liberation Movement. Women's History Review, 25(5), 812-831. https://doi.org/10.1080/09612025.2015.1132878

Gentleman, A. (2015). "It was the scariest thing I've ever done": The Irish women forced to travel for abortions. The Guardian. Available at: https://www.theguardian.com/world/2015/oct/31/abortion-ireland-northernireland-women-travel-england-amelia-gentleman (Accessed 28 July 2018)

Girvin, B. (2008). Contraception, Moral Panic and Social Change in Ireland, 1969-79. Irish Political Studies, 23(4), 555-576. https:// doi.org/10.1080/07907180802452804

Gold, R. B. and Starrs, A. M. (2017). US reproductive health and rights: beyond the global gag rule. Lancet Public Health, 2(3): e122-e123. https://doi.org/10.1016/S2468-2667(17)30035-X

Greenwood, K. and King, L. (1981). Contraception and Abortion, in The Cambridge Women's Studies Group (eds), Women in Society: Interdisciplinary Essays (pp. 168-184). London: Virago.

Guttmacher Institute. (n.d.). Reproductive health in crisis. Available at: https://www.guttmacher.org/tags/reproductive-health-crisis (Accessed 25 July 2018)

Holland, K. and Mac Cormaic, R. (2014). They said they could not do an abortion. I said, 'You can leave me now to die. I don't want to live anymore.' The Irish Times. Available at: https://www.irishtimes.com/news/health/they-said-theycould-not-do-an-abortion-i-said-you-can-leave-me-now-to-die-i-don-t-want-to-live-in-this-world-anymore1.1901258 (Accessed 15 October 2017)

Home to vote. (n.d.). Home to vote. Available at: https://hometovote.com (Accessed 10 April 2018)

House of Commons Hansard. (2017). Reproductive health (access to terminations) bill. UK Parliament. Available at: https://hansard.parliament.uk/commons/2017-03-13/debates/D76D740D-2DDD-4CCB-AC11CODBE3B7D0D8/ReproductiveHealth(AccessToTerminations) (Accessed 10 April 2018)

Inhorn, M. C. (2018). America's Arab refugees: Vulnerability and health on the margins. Stanford: Stanford University Press.

Inhorn, M. C. and Pasquale P. (2009). Rethinking reproductive "tourism" as reproductive "exile." Fertility and Sterility, 92(3), 904-906. https:// doi.org/10.1016/j.fertnstert.2009.01.055

Irish Statute Book. (1861). Offences Against the Person Act. Available at: http://www.irishstatutebook.ie/eli/1861/act/100/enacted/en/print.html (Accessed 29 March 2018)

Irish Statute Book. (1983). Eighth Amendment of the Constitution Act. Available at: http://www.irishstatutebook.ie/eli/1983/ca/8/enacted/en/print (Accessed 10 April 2018)

Irish Statute Book. (2013). Protection of Life During Pregnancy Act. Available at: http://www.irishstatutebook.ie/eli/2013/act/35/enacted/en/pdf (Accessed 10 April 2018)

Jelinska, K. and Yanow, S. (2018). Putting abortion pills into women's hands: realizing the full potential of medical abortion. Contraception, 97, 86-89. https://doi.org/10.1016/j.contraception.2017.05.019

Jolly, M. (2012). Recognising Place, Space and Nation in Researching Women's Movements, Sisterhood and After. Women's Studies International Forum, 35(3), 144-146. https://doi.org/10.1016/j.wsif.2012.03.012 
Kenny, M. (2015). Recollections of The Irish Women's Liberation Movement. History Ireland, 23(5), 48-51.

Knight, D. (2015). Wit and Greece's economic crisis: Ironic slogans, food, and antiausterity sentiments. American Ethnologist, 42(2), 230-246. https:/ / doi.org/10.1111/amet.12127

Larragy, M. (1990). Message from the Six Counties. Spare Rib, 215, 38-43.

Laws, S. (1981). Down There: an Illustrated Guide to Self-Exam. London: Onlywomen Press.

London-Irish Abortion Rights Campaign. (n.d.). Available at: https://londonirisharc.com (Accessed 10 April 2018)

Manchester Metropolitan University News. (2017). Scared, stigmatised and alone: Irish women navigate the abortion trail with little support. Available at: https://www2.mmu.ac.uk/news-and-events/news/story/6373/ (Accessed 3 March 2018)

Martin, A. K. (2000). Death of a Nation: Transnationalism, Bodies and Abortion in Late Twentieth-Century Ireland, in T. Mayer (ed), Gender Ironies of Nationalism: Sexing the Nation (pp. 65-86). London: Routledge.

Mishtal, J. (2017). Quietly ‘beating the system': The logics of protest and resistance under the Polish abortion ban, in S. De Zordo, J. Mishtal and L. Anton (eds), A fragmented landscape: Abortion governance and protest logics in Europe (pp. 226-244). New York and Oxford: Berghahn.

Mullaly, S. (2005). Debating reproductive rights in Ireland. Human Rights Quarterly, 27(1), 78-104. https://doi.org/10.1353/hrq.2005.0008

Nelson, J. (2015). More than Medicine: A History of the Feminist Women's Health Movement. New York: New York University Press. https://doi.org/10.18574/nyu/9780814762776.001.0001

Northern Women's Health Conference, 6-7 July (1985). Bishopsgate Archive. FL/EPH/C/1410.

O'Sullivan, S. (1988). Women's Health: a Spare Rib Reader. Spare Rib, 186, 38-39.

O'Sullivan, S. (ed.) (1987). Women's Health: a Spare Rib Reader. London: Pandora Press.

Oaks, L. (1999). Irish trans/national politics and locating fetuses, in L. M. Morgan and M. W. Michaels (eds), Fetal subjects: feminist positions (pp. 175-198). Philadelphia: University of Pennsylvania Press. https://doi.org/10.9783/9781512807561-011

Olszynko-Gryn, J. (2017). The feminist appropriation of pregnancy testing in 1970s Britain. Women's History Review. https://doi.org/10.1080/09612025.2017.1346869

Scott, A. and Noble, J. (1976). Abortion Conference: Structure and Feminism. Spare Rib, 42, 20-21.

Segal, L. (1979). A Local Experience, in S. Rowbotham, L. Segal and H. Wainwright (eds), Beyond the Fragments: Feminism and the Making of Socialism 2nd Ed (pp. 157-210). London: Merlin Press.

Sheldon, S. (2015). Abortion is still illegal in the UK, thanks to this Victorian law. The Conversation. Available at: https://theconversation.com/abortion-is-still-illegal-in-the-uk-thanks-to-this-victorian-law-48536 (Accessed 10 April 2018)

Sheldon, S. (2016). How can a state control swallowing? The home use of abortion pills in Ireland. Reproductive Health Matters, 24(48), 90-101. https://doi.org/10.1016/j.rhm.2016.10.002

Side, K. (2016). A geopolitics of migrant women, mobility and abortion access in the Republic of Ireland. Gender, Place \& Culture, 23(12), 1788-1799. https:// doi.org/10.1080/0966369X.2016.1262831

The Irish Times. (2018). 'Safe, legal and rare': Full text of Taoiseach's abortion speech. Available at: https://www.irishtimes.com/news/social-affairs/safe-legal-and-rare-full-text-of-taoiseach-s-abortion-speech1.3373468 (Accessed 2 March 2018)

Thomlinson, N. (2016). Race, Ethnicity and the Women's Movement in England, 1968-1993 Basingstoke: Palgrave.

Tuana, N. (2006). The Speculum of Ignorance: The Women's Health Movement and Epistemologies of Ignorance. Hypatia, 21(3), 1-19. https://doi.org/10.1111/j.1527-2001.2006.tb01110.x

UK Government Legislation. (1967). Abortion Act. Available at: https://www.legislation.gov.uk/ukpga/1967/87/introduction (Accessed 29 March 2018)

Wallsgrove, R., Phillips, A. and Nicholls, J. (1979). Ireland Contraceptive Uproar. Spare Rib, 83, 11.

Webb, C. (1986). Postscript, in C. Webb (ed), Feminist Practice in Women's Health Care (pp. 183-187). Chichester: John Wiley \& Sons.

Women Against Imperialism. (1989). Irish Women Against Imperialism. Spare Rib, 204, 57.

Women and Health Weekend in October. (1974). Spare Rib, 30, 19.

Zampas, C. (2017). Legal and political discourses on women's right to abortion, in S. De Zordo, J. Mishtal, and L. Anton (eds.), A fragmented landscape: Abortion governance and protest logics in Europe (pp. 23-45). New York and Oxford: Berghahn. 
Citation: Kasstan, B. and Crook, S. (2018). Reproductive Rebellions in Britain and the Republic of Ireland: Contemporary and Past Abortion Activism and Alternative Sites of Care. Feminist Encounters: A Journal of Critical Studies in Culture and Politics, 2(2), 17. https://doi.org/10.20897/femenc/3885

Copyright $(02018$ by Author/s and Licensed by Lectito BV, Netherlands. This is an open access article distributed under the Creative Commons Attribution License which permits unrestricted use, distribution, and reproduction in any medium, provided the original work is properly cited. 